\title{
Introduction: New Perspectives from PhD Field Research
}

\section{Marika Djolai, Eric Kasper, Ricardo Santos, Shilpi Srivastava and Linda Waldman}

\begin{abstract}
In this introduction, we discuss some of the common issues and experiences expressed in the seven articles of this IDS Bulletin. This issue is a platform for IDS PhD researchers to reflect on their fieldwork experiences, including research-related challenges, as well as cultural and personal encounters along the way. The authors also develop theoretically-informed arguments about their research findings. As editors, we offer further reflections on the importance of fieldwork as part of the transformative experience of 'doing a PhD' in Development Studies. We suggest that the collection of articles in this IDS Bulletin represents a vision for the future of Development Studies research in which the human, relational and public work elements of research are emphasised throughout the contested process of working for change.
\end{abstract}

This IDS Bulletin emerged as a venture of IDS PhD students who felt a need to present their work and ideas, particularly fieldwork experience, to wider audiences who are interested in the field of development. The authors in this collection give voice to important concerns around what it means to do development research. They are not just researchers but agents of development, taking part in the contested process of working for change by doing research with people rather than on people. Through their experiences, we not only get a sense of the transformative process of doing a PhD at IDS, but also a sense of what this generation of scholars can bring to the future of Development Studies.

The experience of completing a $\mathrm{PhD}$ is unique in the career of a research scholar. It is also exciting, innovative and vibrant. Many educational institutions see $\mathrm{PhD}$ students as their lifeblood. As Park argues, doctoral students are the researchers of the future, and their doctoral research generates 'new knowledge, new interpretations and new explanations' (2005: 191). Completing a PhD is an entry into the world of academic practice, which is commonly held to accomplish two things: to make an original contribution to human knowledge, and to shape a student into a research professional. Conceptualised as a 'voluminous contribution' until the late 1980s, individual $\mathrm{PhD}$ dissertations are now required to be thorough, rigorous and sustained pieces of work (Hockey 1995; Park 2005).

Becoming a research professional or academic is not a linear process, consisting only of fieldwork and academic writing, overseen by a supervisor. Rather it is about the dynamic relationships that PhD researchers encounter throughout their PhDs in the process of attending seminars, conferences, workshops, teaching and so forth (Jazvac-Martek et al. 2011).' Through these activities PhD candidates undergo induction into the academic community, experiencing the behaviour and practices and being initiated into the rules, ways of working and discourse of academia (Wellington 2010). Learning through experience and enculturation, rather than simply through acquiring and generating knowledge (Pearson and Brew 2002), is part of the 'process of becoming'; a process in which $\mathrm{PhD}$ researchers are encouraged to partake in activities and to see themselves as part of a community of academic researchers and development practitioners (Crossouard and Pryor 2008).

Grounding empirical research in lived experience among those whose lives are the 
subject of research is a core issue of $\mathrm{PhD}$ fieldwork. Although not always compulsory for completing a $\mathrm{PhD}$, this fieldwork experience, which is such an integral part of creating new knowledge in Development Studies, is often at the heart of the transformational nature of the $\mathrm{PhD}$. With this editorial, we explore the experience of field research in the context of completing a PhD and becoming a professional researcher. This IDS Bulletin, produced and edited by $\mathrm{PhD}$ researchers and IDS Fellows with all the contributions written by IDS PhD candidates who have recently been awarded doctorates, is part of a wider IDS initiative to invest in the professional development of $\mathrm{PhD}$ researchers.

\section{$1 \mathrm{PhD}$ research in Development Studies}

Development Studies is a peculiar academic discipline that engages with the contested phenomenon of 'development' (Sumner and Tribe 2008). What is fundamentally at issue is the highly complex and contested nature of 'change'. To be a PhD researcher in Development Studies is to enter into that milieu, to wrestle with all of the associated moral, ethical, practical and theoretical issues of development. It is also to explore and generate new knowledge(s) at the intersection of such diverse and sometimes contradictory disciplines as economics, anthropology, sociology, agriculture, public health, urban planning, political science, and public affairs.

There is an inescapably normative dimension to Development Studies. It is not simply about understanding social processes, but also about informing change (Sumner 2007). As in other academic disciplines, $\mathrm{PhD}$ researchers generate new knowledge, but in Development Studies this knowledge aims to be transformative and create change. Researchers invariably consider questions such as: 'What kinds of change are desirable? By whom and for whom? At what costs? Who should decide?'. There is a growing demand in the literature (see Chambers 1997; Burns et al. 2013; Manning, Harland Scott and Haddad 2013) that answers to these questions must be sought through relationships with people in situations of development. The authors of the articles in this IDS Bulletin therefore aim to produce research grounded in ethical human relationships through which both the articulation of and the pathways to desired change can be negotiated.

\section{$2 \mathrm{PhD}$ researchers as development agents}

Development Studies also has an advocacy component. For development anthropologists, this has taken the form of resistance to implementation of specific development projects, thus supporting opposition from local communities (Gardner and Lewis 1996). Miller (1993) argued for dissolving boundaries between scholarship and practice when addressing questions important for indigenous peoples. Action researchers have explicitly theorised the researcher's relationship with the research subjects, accepted that objectivity is impossible and acknowledged the researcher as embedded in the social context of the research as an agent (Wicks, Reason and Bradbury 2007). Scholaractivists such as Bookchin et al. (2013: 8) have articulated a vision for militant research "where researchers play a role in actions and share their goals, strategies, and experience of their comrades because of their own committed beliefs and not simply because this conduct is an expedient way to get their data'. The authors of the articles in this IDS Bulletin, in line with these traditions, have made themselves agents of development. They have wrestled with how to use the tools at their disposal - including their own skills, expertise, resources, and identity - to live in the fieldwork setting, to successfully complete the research, and to ethically use their agency and positionality to advocate for their research partners and for the communities they have studied.

\section{$3 \mathrm{PhD}$ researchers and fieldwork}

While some PhD researchers in Development Studies may choose to work exclusively with secondary data, most IDS researchers incorporate some element of personal connection to the field. Within the discipline of anthropology, the idea of field has been contested since the 1990s; two distinct traditions of 'unboundedness' and 'complexity' have become visible that challenge the idea of a singular localised field (Marcus 1995: 1). Appadurai also questions the nature of the 'localness' of the field in a 'globalised' and 'de-territorialized' world (1991: 191, 196). As PhDs, we have led mobile lives taking us to countries across the globe for fieldwork and for further study. We view fieldwork as studying something in the environment where it naturally occurs or that it inhabits; that is, fieldwork as direct experience of life (Preissle and Grant 2004). In doing so, the researcher wishes to be as 
close as possible to the studied 'subject', to understand it, interpret it and reflect on the experience. It is an empirical method that, in human and social sciences, almost always focuses on some form of human action. We draw on a range of field-based methodologies - which include ethnography, participatory methods, open-ended enquiry and action research - that share the essential concept of engaging with the field. IDS PhD researchers have applied this diversity of methods and approaches to their work, blurring the boundaries between qualitative and quantitative; moving between local, national and global scales; and addressing multiple domains of policy in their fieldwork.

Over the past few years, the IDS PhDs have spanned the world, from studying educational returns in post-conflict East Timor to the consequences of returning home in Lebanon; from studying wellbeing and livelihoods in the Potosi mines of Bolivia to understanding the milk scandal in China. As we have traversed across 32 countries, we have studied primary education in rural Kenya; the political ecologies of soyabean farming in Brazil; and ethnic relations in the Bamyan Valley, Afghanistan. These are just a few examples of the diversity of fieldwork projects undertaken at IDS.

The articles presented here are a subset of IDS $\mathrm{PhD}$ topics. They reflect on a range of dimensions associated with fieldwork, all of which are encountered, lived and theorised to different degrees by all $\mathrm{PhD}$ researchers. These include the importance of building trusting relationships with research partners, the ways in which gender is experienced in the fieldwork setting, the experiences of everyday life in the field, embodied experience and positionality. Undertaking fieldwork, for many, forces scholars to acknowledge - as they themselves experience - the ways in which differentials of power play out, including creating or denying researchers' access or opening doors because of who they are or who they are associated with.

\section{Fieldwork and development}

There are seven articles in this IDS Bulletin, covering a variety of geographical locations from Ecuador to Bolivia, Mexico, Kenya, Swaziland, Germany, Nepal, Ghina and India. The topics cover a broad range of issues from the power of wellbeing discourses to water management, migrant children and education, and peacebuilding.

Whitfield and Denskus, in their respective articles, discuss the ways knowledge is constructed and assigned a value through social processes. Whitfield explores governance structures in the Kenyan agricultural landscape, both within the government and international agricultural development agencies. He shows how these structures impact on the politics of knowledge; how seemingly technical issues associated with drought-resistant maize are embedded in complex policy narratives of risk. Presenting a bottom-up view of risk he analyses how farmers tend to experiment with new technological adaptations and understand that such adoption is not risk-free. To the contrary, scientists downplay such uncertainties and claim authority for their knowledge in ways which rely on, and reinforce, structural power relations.

Denskus, while researching aid and development, explores the emergence of what he calls 'a ritual economy' in international peace-building. He shows that performing certain prescribed roles is necessary to maintain authority and acceptance within the community of international peacebuilding organisations. He describes international peace-building conferences as spaces for ritual performances, himself performing the ritual of 'giving a talk' in order to know and engage with this particular transnational and international community of development workers.

Several authors discuss participation and engagement with local communities. LoeraGonzalez, as well as Armijos and Walnycki discuss the importance of participating in collective work events as a way for people to claim membership in their respective communities and contribute to the overall functioning of the collective. However, this is a complex process. In the case of Drinking Water Users' Associations (DWUAs), Armijos and Walnycki show that, on the one hand, managing water through collective action creates a sense of autonomy and community solidarity, but on the other, the retreating state(s) and unequal participation in the water users' associations affect the right to equal access. In her article, Abraham points to greater participation in politics through the gram panchayat system as a pathway to social and political empowerment for 
members of the 'traditionally' marginalised caste with which she was living and working. Again, as she shows, the process of moving from participation to empowerment was not trivial. As political participation began to alter the balance of power, partner non-governmental organisations (NGOs) and active community members faced threats of violence and other pushback. Loera-Gonzalez describes how social and community forums become a platform for the construction and affirmation of wellbeing, explaining collective manual labour as public work which contributed to the sense of community and collective identity.

Some of the researchers found themselves working at the intersection of law and governance. Pong, in her study on education for migrant children in China, shows how civil society is constrained by Chinese laws, and though civil society organisations have been working on the issue for many years, they seem to have had little impact. Simelane works her way through the implementation of legislation designed to increase women's land ownership in Swaziland and interrogates its effectiveness for women's empowerment. These authors give an account of how progressive legislation faces great difficulties when those in power are unenthusiastic about legislation and change. Nonetheless, they show how the existence of legislation has itself opened up spaces for civil agitation and how some people are able to use this in ways that effect positive change.

Gender as a subject of enquiry appears in several articles, both as a reflection on the way gendered positionality impacted the fieldwork experience and as a theme of the article. Pong notes that in the context of migrant education in China, gender is seen as an issue that civil society can organise around, as it is not as politically sensitive as, for example, labour. Simelane examines gender-neutral policies that promote equality in land distribution and concludes that they are ineffective in the absence of suitable strategies and the commitment to implement them effectively.

In different ways, the articles reflect on the authors' personal experiences of fieldwork, the methodological and epistemological particularities of their research, and their connection with the fieldwork sites. In some of the cases the authors spent extensive time (up to one year) among a particular community of people. Armijos and Walnycki spent time living among peri-urban and rural communities in Ecuador and Bolivia respectively, exploring the role of participation in DWUAs. Their article draws on ethnographic data gathered in Ecuador (near Otavalo) and the Zona Sur of Cochabamba, Bolivia. Loera-Gonzalez lived among the indigenous Rarámuri people in the Tarahumara region in Northern Mexico in order to learn about understandings of wellbeing which evoke differentiated ways of living compared to those common to mainstream development thinking and those which occur in the wider society in Mexico. Abraham lived with villagers from a 'traditionally' marginalised caste in the Indian state of Karnataka, in Chikballapur district. Her article discusses the relationship of poor people and a grass roots NGO with the gram panchayat (rural local government) in Donnapalli.

In each of these cases, the researchers did not simply enter and observe these communities as outsiders, but lived among the local people, built trusting relationships with them and with other political actors, and participated in community life. Their anecdotes of life in these communities make a rich contribution to this IDS Bulletin: proving one's worth through contributing to collective manual labour projects, gaining trust through social drinking rituals, and accepting personal inconveniences in order to be around when important events take place. Engaging with the field is not confined to living with the community. Even the authors who did not live in the communities of their research spent extensive time interacting with people in the field. Simelane collected data in Manzini's informal settlement of Moneni, where she employed mixed methodology, including participant observation, while researching the Swaziland Urban Development Project. Whitfield used participatory research with smallholder farmers in Makueni and Nandi counties in Kenya. Denskus conducted his fieldwork in Germany and Nepal while globally engaging with the peacebuilding communities he was studying.

Researchers' positionality is also a quintessential part of fieldwork, which affects one's attitude as a researcher and determines access to research inputs. The gender of the researchers is particularly strongly featured in the articles in 
this IDS Bulletin. Abraham reflects on how being a married woman facilitated her access to relationships with local women that might have been impossible for a male researcher, while being urban allowed her to more easily interact with men. Armijos and Walnycki show how being women helped them access relationships with important women in the communities they lived in, while also noting that 'men were less wary' of them than they might have been of male researchers. For Armijos and Walnycki, not having children made it more difficult to relate to some community members, but it also gave them the space and time required to carry out their research. Simelane offers a rich reflection on being a woman researching the gendered impacts of policy as an authoritative facilitator in a patriarchal society where her role was often assumed to be subservient.

Loera-Gonzalez reflects on his position as a Mexican anthropologist who is at the same time perceived as a 'foreign element' by the Rarámuri communities. Over time, he was slowly integrated into the community, which led to being perceived as Rarámuri by local people, an important stepping stone to open communication and understanding. Denskus moved between three different field sites including a German aid agency, the city of Kathmandu, and the world of academic peace-building conferences. At each point, he reflects on how various aspects of his identity and positionality opened or closed pathways to conducting research. He seems particularly surprised to discover that he felt more 'at home' in Kathmandu than with the aid agency in his native Germany. Pong, in her research on education for migrant children in Beijing, also reflects on the way being an academic researcher led to challenges accessing local government officials, school leaders, and NGO workers, each of whom had an interest in remaining somewhat hidden.

\section{Conclusion}

Through the articles in this IDS Bulletin, we see a vision of $\mathrm{PhD}$ development research as a kind of public work, ${ }^{2}$ requiring the researcher to act as a

\section{Notes}

1 Jazvac-Martek et al. (2011) point out that the significant relationships which impact on $\mathrm{PhD}$ candidates' identities, agency and ability to progress academically also include friends, family members and peers. civic agent, to critically engage with notions of citizenship and politics. The authors of the articles in this IDS Bulletin show, through their own experiences, the importance of connecting to the world outside the university - to the places where development is actually happening. Their stories are far from the technocratic creation of knowledge (Li 2007). They contribute to the growing consensus that an instrumental approach to development, which seeks to 'improve' situations for people by simply applying expert knowledge, is inappropriate and risks negative unintended consequences (Sumner and Tribe 2008).

They have all clearly struggled to come to terms with the contested nature of change, taking care to build working relationships with research partners and reflecting on the subsequent impact on change dynamics of their own positionality and agency in those relationships. These authors can be seen navigating between the need to create new knowledge for their own $\mathrm{PhD}$ and the realisation that knowledge that is not at least in part co-created with research partners has little chance of effecting lasting or ethical change. These new perspectives from IDS $\mathrm{PhD}$ field research offer insights into a variety of research topics, innovations for fieldwork practices, and important reflections on the human experience of $\mathrm{PhD}$ research.

As $\mathrm{PhD}$ researchers, we invest much of ourselves into relationships with other human beings. With our bodies, we thread together different places, physically moving back and forth between the institute in the UK and the research location. Through our lived experience, we incorporate into ourselves the lives of others, their wisdom and their struggles. With our work, and through our writing, we join people and issues together across differences, to share ideas and to mutually play a small part in facilitating positive change. We join our humanity to that of others with the hope that in the end we will have shared our experiences and insights and have moved a little closer to the world as it should be.

2 Harry Boyte (2013) recently made the case that 'public work' is central to democratic citizenship and is thus central to the kind of education universities should provide. 


\section{References}

Appadurai, Arjun (1991) 'Global Ethnoscapes: Notes and Queries for a Transnational Anthropology', in Richard Gabriel Fox (ed.), Recapturing Anthropology: Working in the Present, Santa Fe: School of American Research Press

Bookchin, Natalie; Brown, Pamela; Ebrahimian, Suzahn; colectivo Enmedio; Juhasz, Alexandra; Martin, Léonidas; MTL et al. (2013) Militant Research Handbook, New York University, www.visualculturenow.org/wp-content/ uploads/2013/09/MRH_Web.pdf (accessed 19 December 2013)

Boyte, Harry C. (2013) Reinventing Citizenship as Public Work: Citizen-Centered Democracy and the Empowerment Gap, Kettering Foundation, http://kettering.org/wp-content/uploads/ Reinventing-Citizenship.pdf (accessed 19 December 2013)

Burns, Danny; Howard, Jo; Lopez-Franco, Erika; Shahrokh, Thea and Wheeler, Joanna (2013) Work With Us: How People and Organisations Catalyse Sustainable Change, Brighton: IDS, www.participate2015.org/wp-content/uploads/ 2013/09/Work-with-us_How-people-andorganisations-can-catalyse-sustainablechange.pdf (accessed 19 December 2013)

Chambers, Robert (1997) Whose Reality Counts?: Putting the First Last, London: Intermediate Technology

Crossouard, B. and Pryor, P. (2008) 'Becoming Researchers: A Sociocultural Perspective on Assessment, Learning and the Construction of Identity in a Professional Doctorate', Pedagogy, Culture and Society 16.3: 221-37

Gardner, Katy and Lewis, David (1996) Anthropology, Development and the Post-Modern Challenge, London: Pluto Press

Hockey, J. (1995) 'Change and the Social Science PhD: Supervisors' Responses', Oxford Review of Education 21.2: 195-206

Jazvac-Martek, M.; Chen, S. and McAlpine, L. (2011) 'Tracking the Doctoral Student Experience Over Time: Cultivating Agency in Diverse Spaces', in L. McAlpine and C. Amundsen (eds), Doctoral Education: ResearchBased Strategies for Doctoral Students, Supervisors and Administrators, Amsterdam: Springer

Li, Tania Murray (2007) The Will to Improve: Governmentality, Development, and the Practice of Politics, Durham NC: Duke University Press, http://books.google.co.uk/books?hl=en\&lr=
$\& \mathrm{id}=\mathrm{U}-7 \mathrm{JGmMm} 3 \mathrm{a} 4 \mathrm{C} \& \mathrm{oi}=$ fnd $\& \mathrm{pg}=\mathrm{PP} 6 \& \mathrm{dq}$ $=$ the + will + to + improve $+\&$ ots $=34$ Rnuw2G2 $\mathrm{X} \& \operatorname{sig}=$ WDbODeJjsfJszBvkNekDc-dhmkM (accessed 19 December 2013)

Manning, Richard; Harland Scott, Charlotte and Haddad, Lawrence (2013) 'Whose Goals Count? Lessons for Setting the Next Development Goals', IDS Bulletin 44.5-6: 1-9, www.ids.ac.uk/publication/whose-goals-countlessons-for-setting-the-next-developmentgoals (accessed 19 December 2013)

Marcus, George. E (1995) 'Ethnography in/of the World System: The Emergence of Multisited Ethnography', Annual Review of Anthropology, www.annualreviews.org/doi/pdf/10.1146/ annurev.an.24.100195.000523 (accessed 9 January 2011)

Miller, Marc S. (1993) State of the Peoples: A Global Human Rights Report on Societies in Danger, Boston: Beacon Press

Park, C. (2005) 'New Variant PhD: The Changing Nature of the Doctorate in the UK', Journal of Higher Education Policy and Management 27.2: 189-207

Pearson, M. and Brew, A. (2002) 'Research Training and Supervision Development', Studies in Higher Education 27.2: 135-50

Preissle, J. and Grant, L. (2004) 'Fieldwork Traditions: Ethnography and Participant Observation', in Kathleen Bennett DeMarrais and Stephen D. Lapan, Foundations for Research: Methods of Inquiry in Education and the Social Sciences, London: Lawrence Erlbaum

Sumner, Andrew (2007) 'What are the Ethics of Development Studies?', IDS Bulletin 38.2: 59-68 http://onlinelibrary.wiley.com/doi/10.1111/ j.1759-5436.2007.tb00352.x/abstract (accessed 19 December 2013)

Sumner, Andrew and Tribe, Michael A. (2008) International Development Studies: Theories and Methods in Research and Practice, London: Sage Wellington, J. (2010) Making Supervision Work for You: A Student's Guide, (SAGE Study Skills), London: Sage

Wicks, Patricia Gaya; Reason, Peter and Bradbury, Hilary (2007) 'Living Inquiry: Personal, Political, and Philosophical Groundings for Action Research Practice', in Peter Reason and Hilary Bradbury (eds), The SAGE Handbook of Action Research: Participative Inquiry and Practice, London: Sage 